\title{
E-HRM Practices and its impact on Organizational Performance: A study on the Manufacturing industry in Bangladesh
}

\author{
MD. Tanjil Ahmed \\ Department of Management Studies, Faculty of Business Studies, University of Barisal, Bangladesh.
}

\begin{abstract}
Electronic Human Resource Management (E-HRM) is a relatively new term for developing countries like Bangladesh. Its practice is relatively low for the manufacturing industry since most of the manufacturing industry is labor-intensive, so E-HRM is ignored. With the new era of the twenty-first century where most of the work will get automated, the scale of production will increase and human resource management will become dramatically complex, so E-HRM is the solution. In this research, we find the current level of E-HRM practices on the manufacturing industry in Bangladesh and its impact on organizational performance.

There are three levels of E-HRM named "Informational, Interactional and Transformational". For measuring organizational performance, we look at Six dimensions namely ' Effectiveness, Efficiency, Quality, Timeliness, Finance". For measuring E-HRM practices we chose nine components which are "Recruitment System, Employee System, Information Management System, Salary Management System, Learning and Training System, Idea and Creativity Exchange System, Assessment System, Welfare System, and Career Development System”.

We took NO E-HRM practicing organization as base performance and compare it with E-HRM performing organization to see whether organizational performance increase or not. We found that Informational E-HRM practicing organization performance increases $73 \%$, Interactional E-HRM practicing organization performance increases $197 \%$ and finally, Transformational E-HRM practicing organization performance increases $242 \%$ than No E-HRM practicing organization.

We also compare nine E-HRM practices with organizational performance to see whether there is a significant relationship exist or not. We found that 'Learning and Training System, Salary Management System, Assessment System, Welfare System, Recruitment System, and Career Development System have a positive relationship with organizational performance. On the other hand, Idea and Creativity Exchange System, Information Management System, Employee System have a negative relationship with organizational performance. The more humanistic approach is required in case of idea and creative exchange system and Employee management system since there is a transition period going on in HRM. Information Management is negative due to the size of the organization. Most of the organization in Bangladesh is not large enough to reap the benefits of the information management system. So, in case of a smaller organization, it acts as a burden. Overall There is a significant relationship between E-HRM practices and Organizational performance.

E-HRM benefits to cost must be compared when Implementing E-HRM. Organizations need must consider before implementing E-HRM. Most importantly remember E-HRM is just the advancement of HRM functionality based on sophisticated information, communication, and technology. So, a study must be conducted before implementing E-HRM to see whether the expense worth it or not.
\end{abstract}

Keywords: Electronic Human Resource Management (E-HRM), Organizational Performance, E-HRM Practices, Level of E-HRM

DOI: $10.7176 / \mathrm{EJBM} / 11-6-07$

\section{Introduction}

Information technology is changing the way HR departments handle record keeping and information sharing. It decreases the paperwork substantially and allows easy access to voluminous data. The processing and transmission of digitalized HR information are called Electronic Human Resource Management (Nenwani \& Raj, 2013). EHRM is a "way of implementing HR strategies, policies and practices in organizations through conscious and directed support of and with the full use of web-technology based channels" (Looise \& van Riemsdijk, n.d.).

Organization worldwide has taken various initiatives to increase firm performance through investment in information and Communication Technologies (ICT) with a view to transforming management practices and to increase the efficiency of the organization. As Web technologies matured and organizations enthusiastically adopted them, more and more of the HRM functions got Web-enabled. E-HRM essentially transfers HRM 
functions to employees and managers(Sagum, 2015). They access these functions over a web interface, typically over a corporate intranet. e-HRM can range widely in scope; at the low end, it can be a simple web-based system to access Human Resource (HR) related documents(Sagum, 2015). At the high-end e-HRM is a fully integrated, organization-wide electronic network of HRM-related data, information, services, databases, tools, applications, and transactions that are generally accessible at any time by the employees, managers, and HRM professionals(Hussain, Wallace, \& Cornelius, 2007).

Organizations worldwide have recognized the increasing importance of IT for leveraging human resource management function, thereby leading to the adoption of E-HRM(Hosain, 2017). Information and Communication Technologies (ICT)enable innovative ways of carrying on routine organizational tasks via the power of the virtual work environment. Advanced e-HRM systems typically include Enterprise Resource Planning (ERP) systems, HRM service centers, Interactive Voice Response (IVR), manager and employee portals and web applications.

The empowerment of managers and employees to perform certain chosen HR functions relieves the HR department of these tasks, allowing HR staff to focus less on the operational and more on the strategic elements of HR, and allowing organizations to lower HR department staffing levels as the administrative burden is lightened(Swaroop, 2012). It also helps the organizations to upgrade the HR functions to web-based technology and speed up the flow and implementation of business strategies and processes.

IT possibilities for HRM are endless; in principle, all HR processes can be supported by IT. Computers have simplified the task of analyzing vast amounts of data and they can be invaluable aids in HR management, from payroll processing to record retention(Kumar \& Kamal, 2013). With computer hardware, software and databases, an organization can keep records and information in a better way as well as retrieve them with greater ease(Kumar \& Kamal, 2013). With the state of IT, HRM has become more effective through the use of e-HRM technologies(Winarto, 2018).

"While e-HRM systems indeed offer wide-ranging and unprecedented benefits to organizations, they also entail huge costs and risks (Bell et al., 2006; Weekes, 2006; Anonymous, 2006)"(Pant, Chatterjee, \& Jaroliya, 2008). Such costs emanate not only from the costs of the system but also from those associated with changing the organizational processes, employee training, and the time of the HR and the top management in implementing, adopting and promoting these systems. Risks are inherent in employees not using the system, as well as in employee alienation and resistance to change.

\subsection{Objective of the study}

Despite the theoretical connection between E-HRM practices and organizational outcomes, empirical studies that link the two dimensions are sparse. The objective of the study is to provide insight into the E-HRM practices on the manufacturing industry in Bangladesh and its impact on Organizational Performance. Another objective of the study is to find deep insight into Electronic Human Resource Management.

\section{Literature Review}

E-HRM is a relatively new phenomenon, literature in this area is still emerging. We have based our study on available literature and borrowed heavily from other disciplines like Information Systems, Organizational Culture and Behavior, Organizational Communication, and of course, Human Resource Management. The field of E-HRM is evolving at a rapid pace since the lots of research is being conducted on E-HRM and lots of theory, framework and methodology is being developed as a result. In this literature, we mainly focused on E-HRM practices and organizational performance.

A great deal of research has been done in the field of the contribution of IT into HR. In the early 1960s, personnel management was early to be used for office automation in payroll, benefit administration and maintaining employee records(Ball, 2001). Since past several decades, organization worldwide has taken various initiatives to increase firm performance through investment in ICT with a view to transforming management practices and to increase the efficiency of the organization(H. Ruël \& van der Heijden, 2009; Iqbal \& Ahmad, 2016). Therefore, organization worldwide are trying to understand how the human resource management system influences organizational performance (Davis, Bagozzi, \& R. Warshaw, 1989).

A number of researchers agreed that E-HRM has a capacity to transform the HR department into a strategic function by exploiting technology for "operational, relational and transformational” purposes (Parry \& Tyson, 2011; Iqbal \& Ahmad, 2016). A plenty of literature can be found supporting the assertion that E-HRM enhances 
the HR and organizational effectiveness through cost reduction strategies (such as reducing headcount), shorten the cycle and improving the quality of transactional-HR activities and decreasing administrative burden through devolution of HR task to line manager, improving decision making, ensuring timely completion of work, effective communication, supporting differential labor \& enhancement of control over (Lepak \& Snell, 1998; Hendrickson, 2003; L. LENGNICK-HALL \& MORITZ, 2003).

Distinctive/innovative approaches to HRM increase organizational performance then the E-HRM practices seems a good fit for superior organizational performance (Gardner, Lepak, \& Bartol, 2003; Orlikowski \& Scott, 2008; Marler \& Parry, 2016; Iqbal \& Ahmad, 2016). Recent literature on E-HRM suggested that technology-based practices pushed HRM function in new horizon through fast and accurate decision making, providing a more flexible work environment and to make HRM more efficient (Godard, 2004; Iqbal \& Ahmad, 2016). Studies regarding the implementation of E-HRM make a shift towards addressing the dynamic nature of implementation and using such concepts like innovation, implementation, learning, change management(Keebler \& Rhodes, 2002; H. J. M. Ruël, Bondarouk, \& Van der Velde, 2007). Management (HRM) is undergoing a major change. One agent of change identified by researchers is the use of the Internet and the Web technologies to augment and enhance HRM (L. LENGNICK-HALL \& MORITZ, 2003; Stone, 2005)

In Bangladesh, a few large companies have started to implement electronic HRM in the last few years(Sabrina Jahan, 2014). Only few studies is conducted on Bangladesh regarding E-HRM like "Evaluating the Practices of Electronic Human Resources Management (E-HRM) as a Key Tool of Technology-Driven Human Resources Management Function in Organizations-A Comparative Study in Public Sector and Private Sector Enterprises of Bangladesh" (Islam, 2016), "THE IMPACT OF E-HRM ON ORGANIZATIONAL PERFORMANCE: EVIDENCE FROM SELECTIVE SERVICE SECTORS OF BANGLADESH”(Hosain, 2017) etc.

\subsection{Electronic Human Resource Management practices}

E-HRM practices in an organization vary from organization to organization as most of the organization is different in nature. E-HRM practices can dramatically reduce workload, reduce waste of time and ensure proper human resource management practices. The e-HRM consists of 9 important systems (Chochiang \& Choochote, 2013)described as follows.

\section{A. Recruitment System}

First of all, jobs information is circulated to job applicant through the use of web-based technology. Applicants are allowed to fill the form online and system record applicant information electronically. Recruitment system allows to sort out people based on their skills, ability, CGPA, location, Experience etc. way. Than screen applicant can be called out for a written test or interview. The final step of the online recruitment system concerns greatly with schedules and appointments, which can quickly be confirmed via email, SMS or phone(Choochote \& Chochiang, 2015).

B. Employee System

The employee system can effectively manage the basic data of employees via the networking system(Choochote \& Chochiang, 2015). Employees are given access to edit, delete or add personal information within certain parameters. Furthermore, employees can make leave request through the system and responsible authority can approve it within a short period of time. Furthermore, the employee system can provide service like arrange meeting, conference room booking etc.

C. Basic Organizational Information Management System

Top executives in an organization should have a basic idea about organizational structure, nature of operations, functions, hierarchy etc. A good organizational structure will also reflect in clear vision, mission, and value in order to encourage all employees to achieve a mutual goal(Choochote \& Chochiang, 2015). Doing so employees can clearly understand their roles and responsibilities. The goal of an information system is to provide a clear picture of the organization. providing Timely and accurate information to the right person is the job of an Information Management System.

D. Salary Management System

Salary management, of course, concerns mostly with salary, remuneration and overtime payment received from the organization(Choochote \& Chochiang, 2015). Salary management system covers all aspect of salary including deduction, Tax etc. An employee can get printed copy of a salary slip through the system.

E. Learning and Training System

The learning and training system will encourage all employees to maximize skills, increase knowledge and 
improve attitudes(Choochote \& Chochiang, 2015). Through the system, an employee can book and get training if available. This system can identify enthusiastic and motivated employee and groom them properly to be an asset for the long terms.

\section{F. Idea and Creativity Exchange System}

The idea and creativity exchange system is developed to stimulate the management of self-responsibility for each employee, where different ideas and viewpoints received from meetings, daily conversations, and social network can be shared(Choochote \& Chochiang, 2015). Here employee can share new idea and information through the web which helps the organization to move forward.

\section{G. Assessment System}

Assessment programs help organizations to assess employee fast and accurately. Basically, there are two types of assessment named self-assessment and organization assessment(Choochote \& Chochiang, 2015). Self-assessment motivates employees greatly to achieve their target goal. Organization assessment helps shape employees' career, salary, and trend which way employee will grow.

H. Welfare System

Employees are greatly motivated by the welfare system. Typically, the welfare system includes provident funds, travel expense, gratuity, allowance etc. The welfares offered to the employees are designed to suitably meet the targeted organizational goal in accordance with the limitation of individuals in the database(Choochote \& Chochiang, 2015).

\section{Career Development System}

The career development system is one of the most important one in E-HRM systems. As different employees have different skills and abilities, it is required to bring out their most excellent skills and abilities to ensure that each task can be accomplished thoroughly with regard to their educational backgrounds, work-related experiences and special qualifications to be evaluated by their respective managers, as part of the ambitious goal(Choochote \& Chochiang, 2015).

\subsection{Level of E-HRM system}

There is three level of E-HRM systems (L. LENGNICK-HALL \& MORITZ, 2003) named Informational, Interactional and Transformational. Informational E-HRM consists of publishing organization HRM related information on the internet. Here information like directories, notice, policies etc. are published. Interactional EHRM consist of tasks related to employees interacts with web-based technology. Here task like leave application, performance appraisal etc. are included. Transformational E-HRM transform HRM function itself. Here HRM function integrated with Enterprise system which as a result gets lots of tasks automated. As a result, management has lots of time developing and improving strategy rather than stuck with routine tasks.

\section{Figure 1. Level of E-HRM system}

\section{Levels of E-HR System}

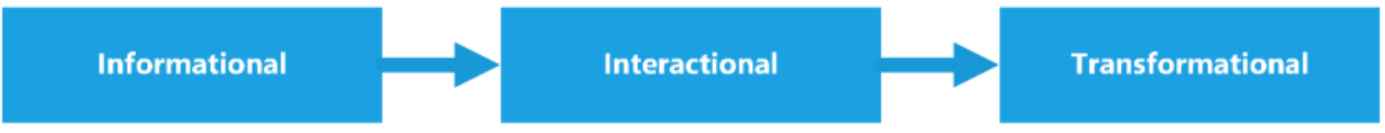

HIGH

\subsection{Organizational Performance Measurement}

Scott Sink and Thomas Tuttle develop first comprehensive conceptual frameworks for identifying measures of organizational performance Sink, D. S., \& Tuttle, T. C. (1989). There they use six measurements for measuring organizational performance which is effectiveness, efficiency, quality, timeliness, finance and finally workplace environment. We have also used the same criteria for measuring our manufacturing organization performance as 
well. It ensures that we properly looked at all the area for measuring organizational performance.

Effectiveness: Erlendsson (2002) defines effectiveness as the extent to which objectives are met ('doing the right things'). Effectiveness main focus is to achieve the objective or output previously mentioned.

Efficiency: Efficiency is the extent to which an activity achieves its goal whilst minimizing resource usage. Thursby (2000, p. 400). An ability to perform well or achieve a result without wasted energy, resources, effort, time or money.

Quality: ISO 9000 defines quality as "Degree to which a set of inherent characteristics fulfills requirements". Here satisfied customer, Satisfied Employee, Defect-free product etc. are counted as quality.

Timeliness: Timeliness are measured in three areas for organizational performance named cycle time, wait time and completed on time.

Cycle time: refers to how much time requires to perform a specific task.

Wait Time: refers to time customer wait for product or services.

Completed on time: refers to whether the task is completed on due time.

Finance: Finance is defined as the management of money and includes activities like investing, borrowing, lending, budgeting, saving, and forecasting. It can be a good indicator of how well a company is performing.

Workplace Environment: Working environment is a broad term and means all your surroundings when working. Your physical working environment is, for example, your work tools as well as air, noise, and light. But your working environment also includes the psychological aspects of how your work is organized and your wellbeing at work. The working environment is a good indicator to measure organizational performance.

\subsection{Conceptual Framework}

The main point of this research is to find E-HRM Practices impact on organizational performance in the manufacturing industry. Our E-HRM practice is independent variables and organizational performance is dependent variables. To measure EHRM practices we took 9 independent variables which make of E-HRM practices. To measure Organizational performance, we took 6 dependent variable which makes of organizational performance. Finally, we measure E-HRM practices impact on organizational performance.

\section{Recruitment System}

\section{Employee System}

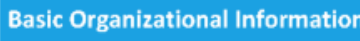

Management System

Salary Management System

Learning and Training System

Idea and Creativity Exchange

System

Assessment System

Welfare System

Career Development System
Effectiveness

\section{Efficiency}

Quality

Timeliness

Finance

Workplace

Environment

Figure 2. Conceptual Framework 


\subsection{Proposed hypotheses}

Based on the literature review and the information obtained, we have concluded the following hypothesis which are:

H1: There is a significant relationship between E-HRM practices and Organizational performance.

$\mathrm{H} 2$ : The higher the level of e-HRM systems implementation in an organization, the better will be the organizational performance.

\section{Research Methodology}

\subsection{Research design}

The research design is a principle plan that specifies the methods and processes for gathering and analyzing the needed information(Quinlan, Zikmund, Babbin, Carr, \& Griffin, 2015). The purpose of the study is to find E-HRM practices impact on organizational performance in the manufacturing industry in Bangladesh. A questionnaire is developed to measure the relationship. Data is collected through a structured questionnaire and interview. So, a quantitative and qualitative method is used for data collection.

\subsection{Population of the study}

The Population is known as a complete set of individuals or objects that share some common characteristic (Quinlan et al., 2015)The population is needed to identify the sample size. The study focuses on E-HRM practices on manufacturing in Bangladesh and its impact on organizational performance. So, our population of the study is

the manufacturing industry from all over Bangladesh. Furthermore, we choose organizations where more than 300 people are employed and white-collar employees as our respondent.

\subsection{Sampling procedure \& Sample size}

The sample is known as a subset or some part of a larger population that is used to measure characteristics of the entire population(Quinlan et al., 2015). The purpose of sampling is to select respondents for surveying on the EHRM practices on the manufacturing industry in Bangladesh and its impact on Organizational Performance. The sampling procedure of this study is convenience sampling method under non-probability sampling technique because this sampling method involves getting participants wherever we find and most importantly wherever is convenient. The sample of the study consist of 223 employees from all over Bangladesh working in the manufacturing industry. The sample is collected from September 2018 to December 2018. Furthermore, we have interviewed $10 \mathrm{HR}$ manager from different manufacturing industry to gain better insight.

\subsection{Questionnaire Design}

A questionnaire is a structured technique for collecting primary data (Bell, 2005). For this study, data is collected through a questionnaire. A questionnaire is constructed in simple language in order to reduce the risk of ambiguity. The questionnaire is being divided into four parts where part A captured the demographic profile of respondents, part B captured Level of E-HRM practices, Part C captured E-HRM practices and finally, part D captured organizational performance. A five-point Likert scale is used for part C and D where 1 stands for Strongly Disagree, 2 stands for Disagree, 3 stands for Neutral, 4 stands for Agree and 5 stands for Strongly Agree.

In part A we asked 9 questions regarding demographic profile. In part B where we asked 4 questions regarding the level of E-HRM practices. In part $C$ we asked 17 questions under 9 subcategories of E-HRM practices. Finally, in part $\mathrm{D}$ we asked 6 organizational performance question.

\subsection{Data collection method}

This research is based on primary data. Primary data is collected through a structured questionnaire and interview. For a structured questionnaire, we have used google form as well as hard copies of the questionnaire to collect data from the respondent. The questionnaire is distributed through Email, LinkedIn, Facebook etc. way. In interviews, we have used face to face interview and over the call interview. For secondary data, we have used different journals, Articles, experimental research, and EHRM related theory. We have drawn our insights from many sources, viz., published articles, interviews with HRM practitioners etc. 


\section{Data Analysis}

\subsection{Reliability test}

Cronbach's alpha $(\alpha)$ was used to check the reliability of the construct. The table represents alpha values with a corresponding reliability category. Hinton (1980) has proposed that reliability categorized as "excellent- 0.90 and above", "high-0.70-0.90", "moderate-0.50-0.70" and "low-below 0.50 " reliability. It is clear from the table that all Cronbach alpha for all construct was within an acceptable range which shows that the instrument is reliable. Thus, it is concluded that instrument components are internally consistent.

\section{Reliability Statistics:}

Construct

E-HRM practices

Organizational Performance

\section{Cronbach's Alpha}

.967

.976
$\mathrm{N}$ of Items

\section{7}

6

From our analysis, we have found that E-HRM practices where we took 17 variables under 9 categories which has excellent reliability level. On the other hand, Organizational Performance where we took 6 variables under 6 categories has excellent reliability as well.

\subsection{Hypothesis Testing}

H1: There is a significant relationship between E-HRM practices and Organizational performance.

\begin{tabular}{lrr|r|r|r}
\multicolumn{1}{c}{} & \multicolumn{4}{c}{ Model Summary } \\
Model & $\mathrm{R}$ & R Square & Adjusted R Square & Std. Error of the Estimate \\
\hline 1 & & $.935^{\mathrm{a}}$ & .874 & .869 & .45179 \\
\hline
\end{tabular}

a. Predictors: (Constant), Career Development System, Employee System, Salary Management System,

Assessment System, Recruitment System, Idea and Creativity Exchange System, Learning and Training

System, Information Management System, Welfare System

Regression analysis assesses the impact of all independent variables on dependent variables. Here we have nine independent variables for E-HRM practices and one cumulative dependent variable for organizational performance. The model summary indicated that about 86.9 percent of the regression model could be accounted for in the study.

\begin{tabular}{llr|r|r|r|r}
\multicolumn{1}{c}{} & \multicolumn{2}{c}{ ANOVA } & & \\
Model & Sum of Squares & df & Mean Square & F & Sig. \\
\hline 1 & Regression & 301.577 & 9 & 33.509 & 164.164 & $.000^{\mathrm{b}}$ \\
\cline { 2 - 7 } & Residual & 43.477 & 213 & .204 & & \\
\cline { 2 - 7 } & Total & 345.054 & 222 & & & \\
\hline
\end{tabular}

a. Dependent Variable: Organizational Performance

b. Predictors: (Constant), Career Development System, Employee System, Salary Management System, Assessment System, Recruitment System, Idea and Creativity Exchange System, Learning and Training System, Information Management System, Welfare System

The $\mathrm{F}$ test provides an overall test of significance of the fitted regression model. The F value of 164.164 indicates that all the variables in the equation are important hence the overall regression is significant. 


\begin{tabular}{|c|c|c|c|c|c|c|}
\hline & & & fficients & & & \\
\hline & & Unstandar & Coefficients & $\begin{array}{l}\text { Standardized } \\
\text { Coefficients }\end{array}$ & & \\
\hline Model & & $\mathrm{B}$ & Std. Error & Beta & $\mathrm{t}$ & Sig. \\
\hline 1 & (Constant) & .261 & .124 & & 2.109 & .036 \\
\hline & Recruitment System & .542 & .062 & .480 & 8.763 & .000 \\
\hline & Employee System & -.109 & .041 & -.119 & -2.663 & .008 \\
\hline & $\begin{array}{l}\text { Information Management } \\
\text { System }\end{array}$ & -.427 & .122 & -.364 & -3.508 & .001 \\
\hline & $\begin{array}{l}\text { Salary Management } \\
\text { System }\end{array}$ & .139 & .076 & .118 & 1.825 & .069 \\
\hline & $\begin{array}{l}\text { Learning and Training } \\
\text { System }\end{array}$ & .337 & .078 & .306 & 4.311 & .000 \\
\hline & $\begin{array}{l}\text { Idea and Creativity } \\
\text { Exchange System }\end{array}$ & -.424 & .096 & -.346 & -4.398 & .000 \\
\hline & Assessment System & .144 & .065 & .150 & 2.198 & .029 \\
\hline & Welfare System & .121 & .120 & .110 & 1.015 & .311 \\
\hline & $\begin{array}{l}\text { Career Development } \\
\text { System }\end{array}$ & .601 & .068 & .582 & 8.813 & .000 \\
\hline
\end{tabular}

a. Dependent Variable: Organizational Performance

From the above analysis, we can see that Learning and Training System, Salary Management System, Assessment System, Welfare System, Recruitment System, and Career Development System have a positive relationship with organizational performance. On the other hand, Idea and Creativity Exchange System, Information Management System, Employee System have a negative relationship with organizational performance. So, a more humanistic approach is required in case of the idea and creative exchange system and Employee management system. Information Management is negative due to the size of the organization. Most of the organization in Bangladesh is not large enough to reap the benefits of an information management system. So, in case of a smaller organization, it acts as a burden. Overall There is a significant relationship between E-HRM practices and Organizational performance, So H1 proved.

$\mathrm{H} 2$ : The higher the level of e-HRM systems implementation in an organization, the better will be the organizational performance

\begin{tabular}{|c|c|c|c|c|}
\hline \multicolumn{4}{|c|}{ Organizational Performance } & \multirow[b]{2}{*}{ Std. Deviation } \\
\hline Level of E-HR Practice & Mean & $\mathrm{N}$ & $\begin{array}{c}\text { Performance } \\
\text { Increase }\end{array}$ & \\
\hline NO E-HRM & 1.3636 & 44 & 0 & .48661 \\
\hline Informational & 2.3526 & 95 & 73 & .55377 \\
\hline Interactional & 4.0536 & 56 & 197 & .43474 \\
\hline Transformational & 4.6667 & 28 & 242 & .24003 \\
\hline Total & 2.8752 & 223 & 512 & 1.24671 \\
\hline
\end{tabular}

We have earlier discussed that there is three level of E-HRM practices which is Informational E-HRM Practices, Interactional E-HRM Practices and finally Transformational E-HRM Practices. If an organization doesn't have any E-HRM practices it is categorized as NO E-HRM practices organization. We have collected 223 samples from 
all over Bangladesh. Among 223 respondents, we found that 44 respondent organization don't perform any form of E-HRM practices, 95 respondent organization perform level 1 which is Informational E-HRM, 56 respondent organization perform Level 2 which is Interactional E-HRM and 28 respondent organization performs level 3 which is Transformational E-HRM.

We took NO E-HRM practice organization as base performance and compare it with the rest of E-HRM performing organization to see whether performance increase or not. We can clearly see that informational E-HRM practicing organization performance is $73 \%$ higher than No E-HRM practicing organization. Interactional E-HRM practicing organization performance is $197 \%$ higher than No E-HRM practicing organization. And finally, Transformational E-HRM practicing organization performance is $242 \%$ higher than No E-HRM practicing organization.

This is so because, through e-HRM systems, organizations are able to reduce the paper trail in HRM processes, reduce work-load on HRM employees as many of the tasks are performed by the employees themselves, and organizational competitiveness improves as HRM personnel are freed to devote time to HRM Development. So, we can say that Higher level E-HRM Practices have a higher level of organizational performance which is proof of our hypothesis $\mathrm{H} 2$.

\section{Findings, Limitation, and Recommendation}

\subsection{Findings from Interview}

Manufacturing industry context is slightly different than the rest of the industry. So, to gain more insight into what is actually going on we interviewed $10 \mathrm{HR}$ employee form 10 different manufacturing industry. Doing so we gain valuable insight which shade light on some different perspective. The findings are given below randomly.

- $\quad$ "owners are not interested to invest heavily on e-HRM systems. it is true mostly in case of smaller organizations"

- "cost of deploying E-HRM system and training personnel is high and the return rate is relatively slow"

- "sometimes it is easier to maintain small firm without using E-HRM"

- $\quad$ "the majority of the employee show some kinds resistant to change when first-time E-HRM is deployed

- $\quad$ "larger organization tends to gain more implement E-HRM"

- " "overexerting on E-HRM benefits and scope can sometimes show negative results"

- "We are using our e-HRM system for internal job postings."

- " "Sometimes e-HRM system is to act as grievance addressing system."

- " "One major downside of these systems is the huge costs."

- $\quad$ "e-HRM systems are helping us improve our bottom line."

- $\quad$ "After working for long hours on a manufacturing shift, employees are not at all motivated to fill in particulars via an e-system."

- $\quad$ "e-HRM systems have a positive effect on growing our business."

- $\quad$ "We do not have an online performance appraisal system - we are using our e-HRM system to mostly collect employee suggestions."

\subsection{Limitations of the Study}

- The study is conducted on the Manufacturing Industry in Bangladesh. As such the findings may vary if the study conducted in another area, Industry, demographic landscape, economy and Time period.

- The respondents may not be found intending to give time to response the question or they may feel uncomfortable.

- The findings of the study will be based on the information provided by the respondents and these are subject to the respondent's bias and partiality.

- Most of the information is collected through google form which can deviate slightly from the actual scenario.

- Time, Money, Access to information and sometimes updated knowledge acts as a limitation of the study. 


\subsection{Recommendation}

E-HRM actually increase organizational performance quite significantly in almost all the area. E-HRM implementation can boost organization efficiency, effectiveness, financial capability etc. it can make an organization focus more on the job rather than day to day task which will farther increase organizational performance. With the new era of the twenty-first century, E-HRM can be used so many innovative ways that we just barely manage to scratch the surface of it. With the introduction of Artificial Intelligence, there are countless possibilities in E-HRM.

As intuitive as it may be, E-HRM benefits to cost must compare by E-HRM in case of Bangladesh. Most of the organization in Bangladesh is lower to medium size in nature. Here organization need must be focused carefully before implementing E-HR. Most importantly remember E-HR is just the advancement of HR functionality based on sophisticated information, communication, and technology. That's why we must remember whether the expense in E-HRM is worth it or not.

\section{References}

Ball, K. (2001). The Use of Human Resource Information Systems: A Survey (Vol. 30). https://doi.org/10.1108/EUM0000000005979

Chochiang, K., \& Choochote, K. (2013). Procedures for the Effective E-HRM.

Choochote, K., \& Chochiang, K. (2015). Electronic Human Resource Management (e-HRM) of Hotel Business in Phuket. International Journal of Advanced Computer Science and Applications, 6(4). https://doi.org/10.14569/IJACSA.2015.060410

Davis, F., Bagozzi, R., \& R. Warshaw, P. (1989). User Acceptance of Computer Technology: A Comparison of Two Theoretical Models (Vol. 35). https://doi.org/10.1287/mnsc.35.8.982

Erlendsson, J., 2002, Value For Money Studies in Higher Education

Gardner, S. D., Lepak, D. P., \& Bartol, K. M. (2003). Virtual HR. Journal of Vocational Behavior, 63(2), $159-179$. https://doi.org/10.1016/S0001-8791(03)00039-3

Godard, J. (2004). A Critical Assessment of the High-Performance Paradigm. British Journal of Industrial Relations, 42(2), 349-378. https://doi.org/10.1111/j.1467-8543.2004.00318.x

Hendrickson, A. R. (2003). Human resource information systems: Backbone technology of contemporary human resources. Journal of Labor Research, 24(3), 381-394. https://doi.org/10.1007/s12122-003-1002-5

Hosain, S. (2017). THE IMPACT OF E-HRM ON ORGANIZATIONAL PERFORMANCE: EVIDENCE FROM SELECTIVE SERVICE SECTORS OF BANGLADESH, 15.

Hussain, Z., Wallace, J., \& Cornelius, N. E. (2007). The use and impact of human resource information systems on human resource management professionals. Information \& Management, 44(1), $74-89$. https://doi.org/10.1016/j.im.2006.10.006

Iqbal, N., \& Ahmad, M. (2016). UNVEILING THE E-HRM-PERFORMANCE LINK: EVIDENCE FROM PAKISTANI BANKING INDUSTRY, 11.

Islam, M. S. (2016). Evaluating the Practices of Electronic Human Resources Management (E-HRM) As a Key Tool of Technology Driven Human Resources Management Function in Organizations-A Comparative Study in Public Sector and Private Sector Enterprises of Bangladesh. SSRN Electronic Journal. https://doi.org/10.2139/ssrn.2958055

Keebler, T. J., \& Rhodes, D. W. (2002). E-HR: Becoming the "Path of Least Resistance." Employment Relations Today, 29(2), 57-66. https://doi.org/10.1002/ert.10041

Kumar, A., \& Kamal. (2013). Impact of Technology Advancement on Human Resource Performance, 4.

L. LENGNICK-HALL, M., \& MORITZ, S. (2003). The Impact of e-HR on the Human Resource Management Function (Vol. 24). https://doi.org/10.1007/s12122-003-1001-6

Lepak, D. P., \& Snell, S. A. (1998). Virtual HR: Strategic human resource management in the 21st century. Human Resource Management Review, 8(3), 215-234. https://doi.org/10.1016/S1053-4822(98)90003-1

Looise, J. K., \& van Riemsdijk, M. (n.d.). Organisational Innovation and HRM, 21.

Marler, J. H., \& Parry, E. (2016). Human resource management, strategic involvement and e-HRM technology. 
The International Journal of Human Resource Management, 27(19), 2233-2253. https://doi.org/10.1080/09585192.2015.1091980

Nenwani, P., \& Raj, M. (2013). E-HRM Prospective in Present Scenario. International Journal, 1(7), 2013.

Orlikowski, W. J., \& Scott, S. V. (2008). 10 Sociomateriality: Challenging the Separation of Technology, Work and Organization. The Academy of Management Annals, 2(1), $433-474$. https://doi.org/10.1080/19416520802211644

Pant, S., Chatterjee, A., \& Jaroliya, D. (2008). e-HR systems implementation: a conceptual framework. AMCIS 2008 Proceedings, 338.

Parry, E., \& Tyson, S. (2011). Desired goals and actual outcomes of e-HRM. Human Resource Management Journal, 21(3), 335-354. https://doi.org/10.1111/j.1748-8583.2010.00149.x

Quinlan, C., Zikmund, W., Babbin, B., Carr, J., \& Griffin, M. (2015). Business Research Methods.

Ruël, H. J. M., Bondarouk, T. V., \& Van der Velde, M. (2007). The contribution of e-HRM to HRM effectiveness: Results from a quantitative study in a Dutch Ministry. Employee Relations, 29(3), $280-291$. https://doi.org/10.1108/01425450710741757

Ruël, H., \& van der Heijden, B. (2009). e-HRM effectiveness in a public sector organization: a multi-stakeholder perspective AU - Bondarouk, Tanya. The International Journal of Human Resource Management, 20(3), 578-590. https://doi.org/10.1080/09585190802707359

Sabrina Jahan, S. (2014). Human Resources Information System (HRIS): A Theoretical Perspective (Vol. 02). https://doi.org/10.4236/jhrss.2014.22004

Sagum, R. A. (2015). ELECTRONIC HUMAN RESOURCE MANAGEMENT ADOPTION IN THE STATE UNIVERSITIES OF THE PHILIPPINES. . . Vol., 8.

Sink, D. S., \& Tuttle, T. C. (1989). Planning and measurement in your organization of the future. Norcross, Ga: Industrial Engineering and Management Press.

Stone, D. (2005). Gueutal, H. G., \& Stone, D. L. (2005). Introduction to the brave new world of eHR. In H. G. Gueutal \& D. L. Stone (Eds.). The brave new world of eHR: Human resources management in the digital age (pp xv-xix). San Francisco: Jossey-Bass.

Swaroop, M. K. R. (2012). E-HRM AND HOW IT WILL REDUCE THE COST IN ORGANISATION. Management Review, 7.

TC 176/SC (2005). ISO 9000:2005, Quality management systems -- Fundamentals and vocabulary. International Organization for Standardization

Thursby, J. G., 2000, 'What Do We Say about Ourselves and What Does It Mean? Yet Another Look at Economics Department Research', Journal of Economic Literature, 38, p. 383.

Winarto, W. (2018). Electronic Human Resources Management (e-HRM) Adoption Studies: Past and Future Research (Vol. 13). https://doi.org/10.19166/derema.v13i1.491 